\title{
TEMPEROS \& CONDIMENTOS: UMA "PITADA" INTERDISCIPLINAR NO ENSINO DE QUÍMICA
}

\section{SEASONINGS AND CONDIMENTS: A "PINCH" INTERDISCIPLINARY IN CHEMICAL TEACHING}

\author{
Thiago Henrique Barnabé Corrêa ${ }^{1}$, Raíza Fonsêca Xavier Lima ${ }^{2}$, João Vitor Cagliari ${ }^{3}$, \\ Priscila Ribeiro Barbosa ${ }^{4}$ \\ ${ }^{1}$ Instituto de Ciências Exatas, Naturais e Educação, Universidade Federal do Triângulo Mineiro, \\ Uberaba/MG, correa.uftm@gmail.com \\ ${ }^{2}$ Curso de Licenciatura em Química, Universidade Federal do Triângulo Mineiro, \\ raizalima97@icloud.com \\ ${ }^{3}$ Curso de Licenciatura em Química, Universidade Federal do Triângulo Mineiro, \\ ${ }^{4}$ Curso de Licenciatura em Química, Universidade Federal do Triângulo Mineiro,
}

\section{RESUMO}

Embora prevista nos documentos oficiais de Educação, a interdisciplinaridade ainda é um desafio nas escolas. A fim de apresentar os alimentos, em especial os temperos e condimentos, como um tema gerador capaz de promover o diálogo entre conteúdos disciplinares, o presente vai ao encontro de explorar a Química no/do cotidiano dos alunos. A riqueza conceitual do tema alimentos e seu potencial educativo é um dos caminhos para aproximar o aluno do conhecimento científico. Como será tratado, muitos fenômenos relacionados aos alimentos carecem de interpretação que pode ser explorada e elucidada em aulas de Química. Nesta ótica, a química torna-se uma abordagem universal e uma linguagem capaz de explicar fenômenos triviais, mas não óbvios, do nosso dia a dia. Assim, o ensino através da Ciência é o escopo desta proposta que contempla uma educação para além da sala de aula.

Palavras-chave: alimentos, interdisciplinaridade, contextualização, ensino de química.

\begin{abstract}
Although provided for in the official documents of Education, interdisciplinarity is still a challenge in schools. In order to present the food, especially seasonings and condiments, as a generator theme that promotes dialogue between subject content, this will appeal to explore the chemistry in / of the students' daily lives. The conceptual richness of the theme food and its educational potential is one of the ways to approach the student of scientific knowledge. As will be discussed, many phenomena related to food lack of interpretation that can be explored and elucidated in chemistry classes. In this approach, the chemical becomes a universal approach and a language capable of explaining trivial phenomena, but not obvious, of our day to day. Thus, teaching through Science is the scope of this proposal which includes an education beyond the classroom.
\end{abstract}

Key words: food, interdisciplinarity, contextualization, chemistry teaching. 


\section{INTRODUÇÃO}

De modo a superar o tratamento fragmentado dos conteúdos escolares e contribuir para a construção de uma visão mais adequada e articulada destes, a interdisciplinaridade vem sendo colocada como uma necessidade formativa em diferentes níveis de ensino. Entendida como uma consequência natural da contextualização, pois ela decorre da perspectiva desta última (ABREU; LOPES, 2010), muitos trabalhos trazem a interdisciplinaridade como uma abordagem que pode tornar mais significativa a aprendizagem dos conceitos científicos (CORREIA et al., 2004, p. 19), permitindo a integração dos conteúdos disciplinares, especialmente quando se utiliza temas cotidianos de grande relevância como alimentos.

Diante do apresentado e a partir da temática Temperos \& Condimentos, este trabalho busca, apoiado em exemplos cotidianos, explorar a Química por trás dos alimentos, tecendo um diálogo contextualizado com outros conteúdos disciplinares.

\section{O SAL ATRAVÉS DOS TEMPOS}

Consumir certos alimentos, nem sempre é uma tarefa prazerosa. Para tal, aprendemos que além do cozimento, o emprego de condimentos pode realçar o sabor da comida, aumentando o interesse pelo prato. Um exemplo bem claro e simples que ocorre no cotidiano é o caso da Lactuca sativa, nome cientifico de uma das 50 hortaliças mais comercializadas no Brasil, e conhecida popularmente como alface. Ainda que não exija muito preparo, podendo ser consumida in natura, a alface apresenta pouca atratividade ao paladar, levando a maioria dos apreciadores a resolver este "problema" insosso com temperos prontos ou adicionando limão/vinagre e sal.

Existe no mercado uma vasta variedade de temperos e condimentos que garantem aos alimentos melhor aroma e sabor. No entanto, o uso destes surgiu frente a necessidade do homem em conservar a aparência dos alimentos e disfarçar determinados odores. Embora tenhamos hoje fácil acesso aos alimentos, nem sempre isso foi realidade, e garantir a conservação destes foi por muito tempo um de nossos maiores desafios frente a inexistência de equipamentos como a geladeira.

Mais importante do que domesticar plantas e animais selvagens, estocar os alimentos foi decisivo para uma vida melhor, tendo o sal um papel fundamental na história no que diz respeito à conservação. Adotado como moeda na Roma antiga, a remuneração do trabalho humano já foi feita com porções de sal como pagamento aos 


\section{Ensino, Saúde e Ambiente - V9 (3), pp. 140-159, Dez. 2016}

soldados, dando origem a palavra salário. Eleito como um alimento divino pelos romanos, o qual ajudava na cicatrização de feridas de batalhas, o sal era considerado uma dádiva de Salus, a deusa da saúde.

O uso do sal como conservante está associado a capacidade de desidratar o alimento e os organismos indesejáveis responsáveis por sua deterioração. Graças ao fenômeno 'osmose' - movimento da água através de uma membrana semipermeável, do meio de menor concentração de soluto para o de maior concentração - as células dos microrganismos, como bactérias, perdem água para o meio externo (extracelular), causando sua morte. Isso explica, inclusive, o porquê sentimos sede quando ingerimos alimentos extremamente salgados, ou porquê não podemos beber a água do mar. A elevada concentração de sal (soluto) na água (solvente) força o nosso organismo a liberar a água de dentro das células (intracelular) para diluir o excesso de sal, sendo a osmose o fenômeno responsável por este equilíbrio celular dinâmico e natural. Com isso, não seria errado dizer que beber muita água salgada pode nos desidratar.

\section{A QUÍMICA DO CHORO}

Formando uma dupla quase obrigatória na cozinha, o alho e a cebola estão entre os temperos mais utilizados na culinária brasileira. Além do valor gastronômico, há milhares de anos ambos têm sido empregados para fins terapêuticos, fazendo parte da medicina popular. Entre os registros mais antigos há um papiro médico egípcio, datado de cerca de 1550 anos a.C., o qual descreve vinte e duas indicações do alho como um remédio eficaz para uma variedade de doenças, tais como problemas do coração, dores de cabeça e tumores (PEIXOTO, 1994).

Característicos por seu odor marcante, estes bulbos não possuem apenas semelhanças biológicas (taxonômicas) - como pertencer ao mesmo gênero - mas, principalmente, semelhanças químicas (Tabela 1).

Tabela 1: Nome científico do alho e cebola

\begin{tabular}{cc}
\hline & $\begin{array}{c}\text { Nome científico (Gênero } \\
\text { espécie) }\end{array}$ \\
\hline Alho & Allium sativum \\
\hline Cebola & Allium cepa \\
\hline
\end{tabular}

Fonte: Acervo pessoal 
O cheiro intenso provocado pelo corte do alho e da cebola deve-se aos compostos de enxofre neles existentes (PEIXOTO, 1994). Cortar, amassar ou triturar esses bulbos resulta na destruição de milhões de células que liberam seu conteúdo. Nelas estão, entre outras substâncias, o 1-propenil-L-cisteína sulfóxido, o qual sofre decomposição por ação de enzimas chamadas alinases, dando origem ao ácido propenilsulfênico, transformando-se espontaneamente em tiossulfinato $\left(\mathrm{C}_{6} \mathrm{H}_{10} \mathrm{~S}_{2} \mathrm{O}\right)$, um dos responsáveis pelo seu forte cheiro (Figura 1).

Figura 1: Formação de tiossulfinato a partir de 1-propenil-L-cisteina sulfóxido

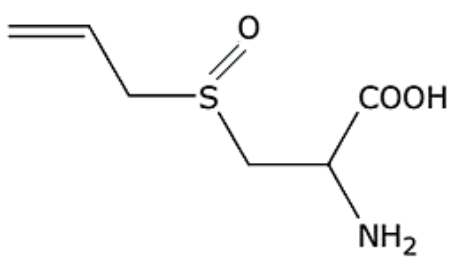

1-propenil-L-cisteina sulfóxido<smiles>CC=CSO</smiles>
ácido 1-propenilsulfênico
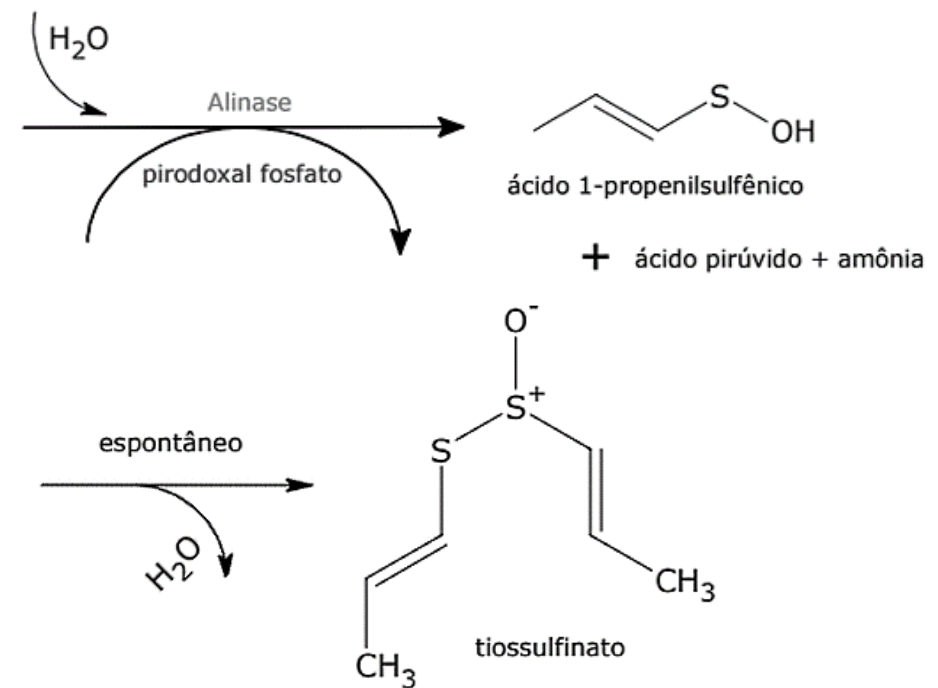

Fonte: Chemello (2005)

Outra molécula associada ao odor desses bulbos, em particular ao do alho, é a alicina $\left(\mathrm{C}_{6} \mathrm{H}_{10} \mathrm{~S}_{2} \mathrm{O}\right)$, um líquido quimicamente instável e sem cor (RANA et al., 2011). Apesar da alicina (Figura 2) e do tiossulfinato estarem presentes em ambos, nota-se que o alho e a cebola não exalam qualquer odor se intactos.

Figura 2: Fórmula estrutural da Alicina<smiles>C=CCSS(=O)CC=C</smiles>

Fonte: Acervo pessoal

Perceba que tanto a molécula de tiossulfinato como a de alicina são isômeros, ou seja, possuem a mesma fórmula molecular e, consequentemente, o mesmo número de 
espécies químicas (átomos). Entretanto, na prática, elas têm odores característicos e distintos, de modo que a percepção de seu cheiro está relacionada a estrutura das moléculas odoríferas, uma vez que estas, com a sua geometria própria, encaixam-se em receptores localizados nas células da cavidade nasal (PEIXOTO, 1994).

Diante das semelhanças descritas e por apresentarem estruturas análogas (dois átomos de enxofre e um de oxigênio), talvez você esteja se perguntando o por que não choramos quando picamos o alho, assim como acontece com a cebola. A resposta para este curioso fato foi dada a pouco tempo, quando pesquisadores japoneses descobriram que o forte odor da cebola não está associado às lagrimas. Ou seja, o fator lacrimogênio não é o tiossulfinato. Então, qual molécula seria a responsável pelo choro involuntário?

Em pesquisa publicada na revista Nature (2002), os japoneses apresentaram ao mundo a enzima $L F$ sintase - encontrada somente na cebola. Através desta enzima, o ácido propenilsufênico, precursor do tiossulfinato, é transformado em um composto altamente volátil, o propanotial-S-óxido (IMAI et al., 2002), o qual ao chegar até o fluido que lubrifica o globo ocular reage com água e forma substâncias, como o propanal e o ácido sulfúrico, provocando irritação das terminações nervosas dos olhos (Figura 3). Assim, na tentativa de neutralizar o efeito, e causar menos desconforto, as glândulas lacrimais entram em ação, fazendo-nos chorar.

Figura 3: Reação do propanotial-S-óxido com água

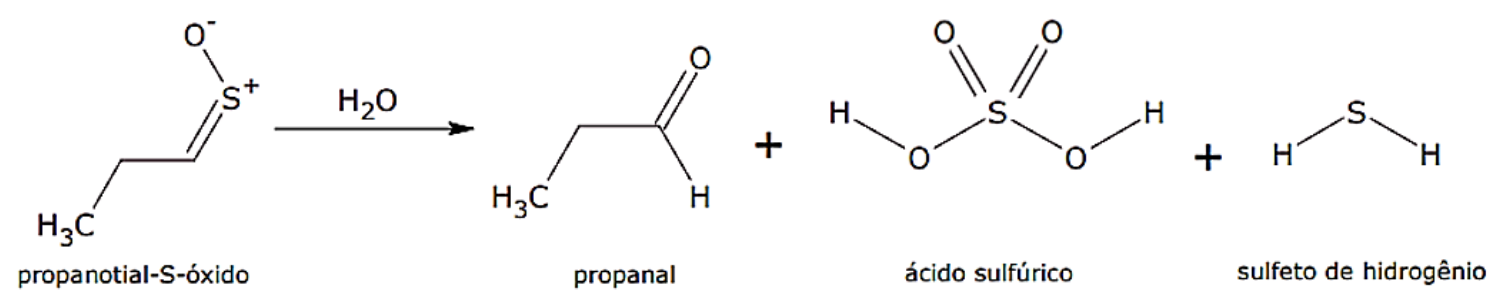

Fonte: Chemello (2005)

Certamente você já deve ter percebido que a cebola, após ser refogada, não tem mais o mesmo efeito nos nossos olhos, e isso pode ser explicado pela inativação/desnaturação da enzima $L F$ sintase em decorrência da alta temperatura. Muitos truques são indicados para se evitar o lacrimejar quando cortamos cebolas. Por exemplo, descascar uma cebola debaixo de água corrente ou molhar as mãos e a cebola antes de corta-la reduz o efeito da substância sulfurosa, uma vez que grande parte do gás reage com a água da torneira, das mãos ou da cebola, evitando que chegue aos nossos 
olhos. Resfriar a cebola antes de seu uso também é uma opção, pois as reações químicas que nos levam até às lágrimas ocorrem mais lentamente. Ou ainda mergulhar a cebola durante alguns minutos em água quente, o que inibe a ação da enzima citada.

\section{TUDO QUE ARDE CURA?}

Há muitas controvérsias quanto a origem da pimenta, no entanto, é inegável considerar que sua popularização se deu com as Grandes Navegações no século XV. Com a queda de Constantinopla e do Império Bizantino pelos Otomanos, em 1453 as principais rotas comerciais de seda, porcelana, prata, ouro e especiarias foram bloqueadas, motivando a Europa (portugueses e espanhóis) a enfrentar o oceano Atlântico e contornar a África em busca de um novo caminho para se chegar às Índias como era chamado o Oriente.

Embora tão apreciada e valorizada pelos europeus, existem evidências de que a pimenta já era conhecida nas Américas antes mesmo de seu descobrimento. Em relato feito pelo marinheiro alemão Hans Staden - o qual foi prisioneiro dos índios Tupinambás durante nove meses no Brasil (1554) -, este traz o uso da pimenta como arma química por parte dos nativos. Segundo Staden, os índios faziam grandes fogueiras e queimavam pimenta para afugentar os invasores num primitivo, e então conhecido, 'gás de pimenta' (SILVA; NEVES; FARIAS, 2011).

Empregada atualmente com outros temperos na comida como conservante e para realçar o sabor, a pimenta é o segundo condimento mais utilizado no mundo, perdendo somente para o sal de cozinha (MASSABNI, 2010). Famosa por sua pungência, a pergunta científica óbvia que todos fazem é: por que a pimenta arde?

Os principais constituintes químicos da pimenta associados à sua ardência são as amidas piperina $\left(\mathrm{C}_{17} \mathrm{H}_{19} \mathrm{O}_{3} \mathrm{~N}\right)$, chavicina $\left(\mathrm{C}_{17} \mathrm{H}_{19} \mathrm{O}_{3} \mathrm{~N}\right)$ e capsaicina $\left(\mathrm{C}_{18} \mathrm{H}_{27} \mathrm{O}_{3} \mathrm{~N}\right)$. Encontradas em concentrações que podem variar entre 0,1 até $1 \%$ de seu peso, o que parece pouco, essa pequena quantidade é suficiente para produzir a tão apreciada e

típica ardência (Figura 4). Cabe ressaltar que esses compostos não se apresentam uniformemente distribuídos no fruto, mas se concentram nas sementes e na cobertura que as rodeia, o endocarpo (MASSABNI, 2010; CEDRÓN, 2013). Dessa maneira, quando comemos pimenta - principalmente do gênero Capsicum - devemos ter cuidado com estas partes, as quais podem ser retiradas para suavizar tal sensação. 
Figura 4: Fórmula estrutural da piperina, chavicina e capsaicina<smiles>O=C(/C=C/C=C/c1ccc2c(c1)OCO2)N1CCCCC1</smiles>

Piperina<smiles>O=C(/C=C\C=C/c1ccc2c(c1)OCO2)N1CCCCC1</smiles>

Chavicina<smiles>COc1cc(CNC(=O)CCCC/C=C/C(C)C)ccc1O</smiles>

\section{Capsaicina}

Fonte: Acervo pessoal

Como é possível perceber, todas as moléculas apresentadas possuem semelhanças estruturais que, possivelmente, estão relacionadas a sensação "picante" destas, como um átomo de nitrogênio $(\mathrm{N})$ vizinho a um átomo de carbono (C) duplamente ligado a oxigênio $(\mathrm{O})$, além de um único anel aromático.

Considerada menos "ardida", mas que se adapta a essa teoria, a zingerona $\left(\mathrm{C}_{11} \mathrm{H}_{14} \mathrm{O}\right)$ - um dos princípios ativos do gengibre - também tem um anel aromático com os mesmos grupos $\mathrm{OH}$ e $\mathrm{H}_{3} \mathrm{C}-\mathrm{O}$ (radical vanilil), ligados como na capsaicina (Figura 5). Entretanto, nota-se nesta a ausência do átomo de nitrogênio, o que significa que a ardência depende, inclusive, do restante da molécula, o que vai alterar a ligação com os receptores nos neurônios.

Figura 5: Fórmula estrutural da zingerona<smiles>COc1cc(CI(I)C(C)=O)ccc1O</smiles>

Fonte: Acervo pessoal

Apesar do pimentão intimidar por seu tamanho, além de pertencer ao gênero Capsicum, sabemos que esta pimenta curiosamente não possui pungência. Em pesquisa 
realizada por Ohse et al. (2010), estes identificaram mutações no DNA da planta e deleções (partes que foram apagadas ao longo da sua história evolutiva) que impedem o funcionamento da enzima que codifica o gene da capsaicina (Pun1), responsável pelo ardor.

Em 1912, a apreciação pelo poder picante das pimentas foi além da culinária, tornando-se objeto de interesse do farmacêutico norte-americano Wilbur Scoville, o qual desenvolveu uma escala que mede o grau de ardência das pimentas, chamada em sua homenagem de 'escala de Scoville'. É importante destacar que estudos sobre a síntese da piperina e da capsaicina, assim como de suas atividades farmacológicas, não são recentes, sendo desenvolvidos desde o século XIX (Buchohz em 1816; Thresh em 1846; Hogyes em 1878; e, Hugheimer em 1882). Sabe-se que graças a seus compostos, a pimenta auxilia na quebra de gordura no tecido adiposo, além de ser um excelente alimento termogênico, acelerando o metabolismo e o gasto energético durante a digestão. Os especialistas acreditam, ainda, que a capsaicina ajuda a dessensibilizar as fibras nervosas que transportam os sinais da dor até o sistema nervoso central, o que a torna um aliado contra determinadas patologias (artrites e artroses) e um valioso princípio ativo para medicamentos.

Esses compostos (piperina, chavicina e capsaicina), denominados alcaloides, são sintetizados pelas plantas como um mecanismo de defesa (adaptação evolutiva) contra o ataque de animais; contudo, o provérbio popular "pimenta nos olhos dos outros é refresco" torna-se realidade para os pássaros e alguns insetos, já que não são afetados por sua pungência como ocorre com os mamíferos, tornando-os, desta forma, vitais para a propagação/disseminação das sementes.

Afinal, por que nós sentimos o sabor picante da pimenta? A sensação picante que experimentamos quando ingerimos a pimenta não é realmente um sabor, mas uma resposta de nossos receptores nervosos de dor (nociceptores) a um estímulo químico. Estudos mostram que tais moléculas se ligam a nociceptores conhecidos como TRPV-1 (receptor de potencial transiente, vanilóide 1), presentes em membranas de neurônios para dor e sensação de calor. O TRPV-1 é um canal de cálcio que se abre quando exposto a temperaturas entre 37 e $45^{\circ} \mathrm{C}$. A exposição prolongada à capsaicina pode causar morte celular por excesso de influxo de íons cálcio, que é letal para a célula (daí seu uso potencial no tratamento de câncer, levando à morte das células tumorais). Na presença da capsaicina, por exemplo, esse canal se abre mesmo em temperaturas inferiores a $37^{\circ} \mathrm{C}$, o que explica o fato de sentirmos a sensação de queimação (dor) e 
calor quando ingerida (Le COUTER; BURRESON, 2006; NUNES, et al., 2014). O sinal deflagrado é transmitido até o cérebro através do nervo trigêmeo, o qual se liga a região dos olhos, fazendo estes lacrimejarem.

Algumas pessoas sentem prazer ou contentamento após ingerir uma comida picante, sensação esta relacionada a liberação de endorfina - um neurotransmissor produzido no cérebro (glândula hipófise) como resposta natural do corpo à dor, ajudando a relaxar e gerando bem-estar e prazer. Esse fenômeno talvez explique o porquê essas pessoas gostam tanto de comida apimentada, pois quanto mais forte a pimenta, maior a dor, e, consequentemente, maiores os traços de endorfina produzidos em outras palavras - maior prazer (Le COUTER; BURRESON, 2006).

Tanto a piperina quanto a chavicina e a capsaicina possuem caráter lipofílico (solúvel em solventes como álcool, éter, benzeno, acetona e óleos vegetais). Apesar de terem uma função amida, assim como, a função éter e fenol na última, possibilitando ligações de hidrogênio, essa característica não é suficiente para torná-las muito hidrossolúveis. Prever a solubilidade de estruturas orgânicas complexas não é uma tarefa fácil, mas, de uma forma geral, quanto maior a cadeia carbônica e quanto menos grupos polares, menor é a sua solubilidade em solventes fortemente polares, como a água. Nesse sentido, não é difícil explicar o porquê conservas de pimenta em óleo, como no azeite, são mais picantes do que conservas em vinagre ou cachaça. Graças ao poder de extração de substâncias apolares, o molho de uma pimenta mais fraca pode ter uma fase oleosa nada inocente.

Então, a pergunta que nos resta é: beber água para amenizar o poder da pimenta é uma estratégia eficaz assim como retratam filmes e desenhos? Quimicamente, a água não é o recurso mais indicado devido a sua polaridade, entretanto, a água gelada pode, temporariamente, "adormecer" o tecido celular da boca, tirando sua sensibilidade. Uma boa saída para se livrar do efeito picante da pimenta é a ingestão de um alimento "gorduroso", como o leite integral de vaca, o qual apresenta uma concentração média de gordura de 3,7\% (VERRUMA; SALGADO, 1994). Atribui-se, ainda, a caseína (Figura 6) - uma proteína relativamente hidrofóbica presente no leite e derivados - a capacidade de combater a ardência causada pela pimenta. Isso se dá porque a caseína quebra a ligação entre a capsaicina e os receptores do paladar interagindo com a molécula da pimenta. Outra forma de se livrar da ardência, é ingerir alimentos que estimulam a salivação (doces e ácidos). 
Figura 6: Fórmula estrutural da caseína

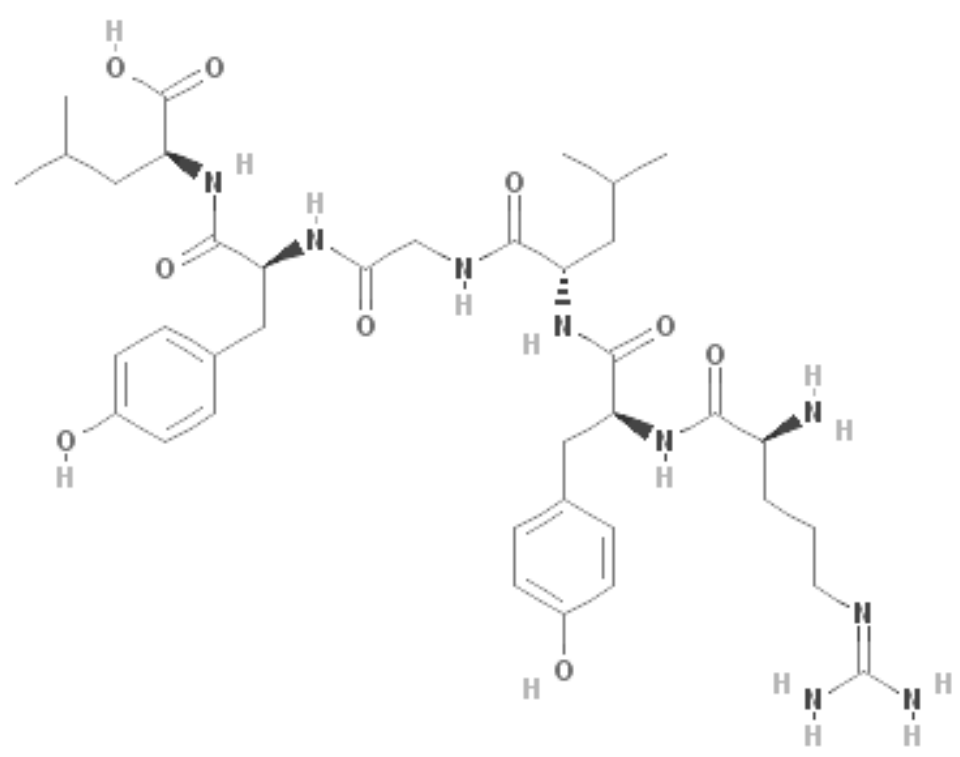

Fonte: PubChem

Ainda que a fama da pimenta seja atribuída a sua pungência, a frase "o que arde cura" ganha sentido frente às inúmeras propriedades medicinais indicadas pela Ciência. Por apresentar alto teor de vitamina C (antioxidante), poder antibacteriano, antiinflamatório e antibiótico, e por conter vários nutrientes essenciais à saúde humana, a pimenta é encontrada em diversos pratos por seu aspecto aromático e terapêutico (STADLER, 1999). Segundo Massabni (2010), a pimenta tem sido objeto de investigação de muitas pesquisas nos últimos anos e os resultados destas indicam seu emprego na prevenção e no tratamento de várias doenças. Alguns trabalhos demostram que a capsaicina é um expressivo anticoagulante, pois ajuda a baixar a pressão arterial, reduzindo o colesterol e evitando a formação de coágulos sangüíneos que podem provocar infarto, trombose e derrame cerebral.

\section{UM CONDIMENTO QUE VALIA OURO}

Uma das especiarias mais cobiçadas na Europa durante o século IV, a nozmoscada (Myristica fragrans) representava um símbolo de status para a nobreza e uma forma de escambo - moeda de troca - na comercialização de produtos, sendo que quinhentos gramas (500 g) de noz-moscada correspondia ao valor de uma vaca inteira ou três ovelhas e dois bezerros. 
Além do valor comercial, esta especiaria foi um importante aliado no século XIV contra a peste bubônica - mais conhecida como peste negra - que chegou a matar 1/3 da população europeia no fim da Idade Média. Contudo, qual a relação da nozmoscada no combate a esta pandemia?

Assim como a pimenta, a noz-moscada vem sendo estudada como uma alternativa para o controle de pragas em virtude das propriedades inseticidas de seus compostos, como: miristicina, elemicina, safrol e isoeugenol (sendo este último o principal responsável pelo seu aroma) - (Figura 7). É possível perceber, também, semelhanças estruturais destes compostos com as moléculas de piperina, chavicina e capsaicina, presentes na pimenta, o que pode estar relacionado com a propriedade descrita.

Na Idade Média, acreditava-se que a noz-moscada era capaz de repelir a peste negra que, posteriormente, foi associada às pulgas dos ratos que estavam contaminadas pela bactéria Yersinia pestis, causadora da infecção. Conhecida a atividade inseticida da noz-moscada, torna-se mais fácil entendê-la como uma profilaxia (medida de prevenção) desta moléstia, agindo como um repelente natural das pulgas.

Figura 7: Fórmula estrutural da miristicina, elemicina, safrol e isoeugenol
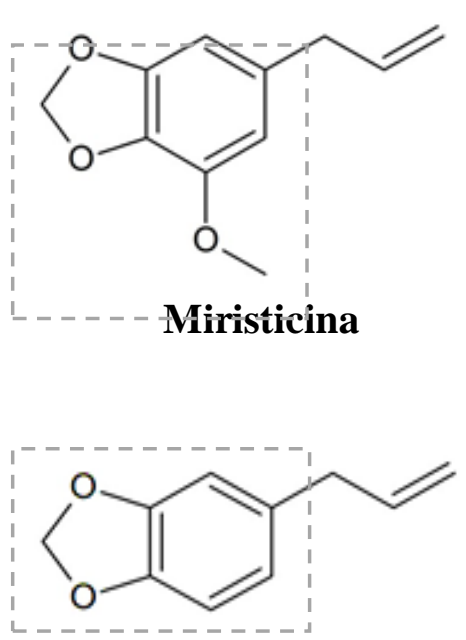

Safrol
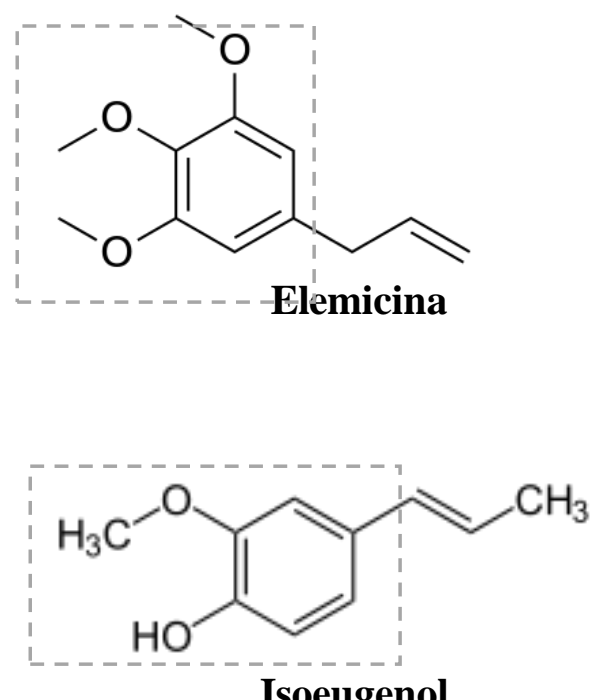

Isoeugenol

Fonte: Acervo pessoal

Além de talismã contra a peste negra, a noz-moscada era considerada a “especiaria da loucura” (Le COUTEUR; BURRESON, 2006). De acordo com Alonso (1998), a propriedade alucinógena desta é decorrente das moléculas miristicina e 
elemicina. O referido autor cita um registro de relato de 1576 como o primeiro caso de intoxicação por uma mulher inglesa grávida que consumiu entre 10 a 12 nozes, apresentando um quadro de embriaguez e delírio. Para Le Couteur e Burreson (2006), ainda não é possível provar que essas moléculas são as causadoras desse efeito psicoativo, pois é mais provável que elas sejam convertidas em nosso corpo, por alguma via metabólica ainda desconhecida, a quantidades mínimas de compostos que seriam análogos às anfetaminas. Frente ao exposto, o safrol, também encontrado na nozmoscada, torna-se um forte candidato desta lista, uma vez que difere da estrutura da miristicina unicamente pela falta de um $\mathrm{OCH}_{3}$, além de ser utilizado como matéria prima para a síntese de ecstasy (3,4-metilenedioxi-N-metianfetamina - MDMA) (Figura 8) - uma anfetamina estimulante que exerce seus efeitos sobre os neurônios que liberam dopamina, adrenalina, noradrenalina e serotonina (RETONDO; FARIA, 2009).

Figura 8: Via de reação do safrol para formação de ecstasy<smiles>C=CCc1ccc2c(c1)OCO2</smiles>

Safrol

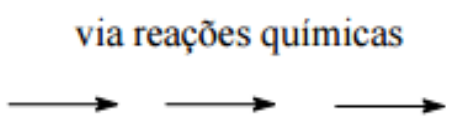

Fonte: LeCouteur \& Burreson (2006)

As estruturas de alguns compostos encontradas na noz-moscada (safrol e miristicina) e na pimenta (piperina e chavicina) não são as únicas semelhanças entres estas especiarias, de modo que propriedades apresentadas pela literatura (inseticida, estimulante e termogênica) são comuns em ambas.

\section{SEPARADAS PELA DERIVA CONTINENTAL}

Outra especiaria que impulsionou as Grandes Navegações e tem emprego garantido na culinária, desde pratos doces à salgados, é o cravo-da-índia (Syzygium aromaticum). Curiosamente, o odor marcante desta planta se deve ao eugenol, um composto muito semelhante ao isoeugenol, encontrado na noz-moscada (Figura 9).

Figura 9: Formula estrutural do eugenol e do isoeugenol 
Ensino, Saúde e Ambiente - V9 (3), pp. 140-159, Dez. 2016<smiles>C=CCc1ccc(O)c(OC)c1</smiles>

Eugenol

(cravo-da-índia)<smiles>C/C=C/c1ccc(O)c(OC)c1</smiles>

Isoeugenol

(noz-moscada)

Fonte: Acervo pessoal

Tomando como ponto de partida suas estruturas, a única diferença entre essas moléculas aromáticas está no posicionamento de uma dupla ligação, o que torna estes compostos isômeros $\left(\mathrm{C}_{10} \mathrm{H}_{12} \mathrm{O}_{2}\right)$ - isomeria de posição. A semelhança entre as moléculas é suficiente para garantir propriedades comuns (inseticida, fungicida e analgésica), porém, tal diferença, ainda que pequena, é a responsável pelos aromas distintos e característicos destas.

Ao analisarmos suas taxonomias podemos notar que tanto a noz-moscada como o cravo-da-índia não pertencem ao mesmo gênero, espécie ou família (Tabela 2). Mas, por que suas moléculas seriam tão parecidas?

Tabela 2: Nome científico da noz-moscada e do cravo-da-índia

\begin{tabular}{ccc}
\hline & Nome científico (Gênero espécie) & Família \\
\hline Noz-moscada & Myristica fragrans & Myristicaceae \\
\hline Cravo-da-índia & Syzygium aromaticum & Myrtaceae \\
\hline & Fonte: Acervo pessoal
\end{tabular}

Uma hipótese a ser levantada toma como base a origem dessas plantas: o Arquipélago das Molucas, na Indonésia. Contudo, o cravo-da-índia e a noz-moscada são típicas de ilhas diferentes (Ternate e Tidore; Banda), com cerca de $670 \mathrm{Km}$ de distância (Figura 10). 


\section{Ensino, Saúde e Ambiente - V9 (3), pp. 140-159, Dez. 2016}

Figura 10: Imagem via satélite do arquipélago das Molucas, Indonésia

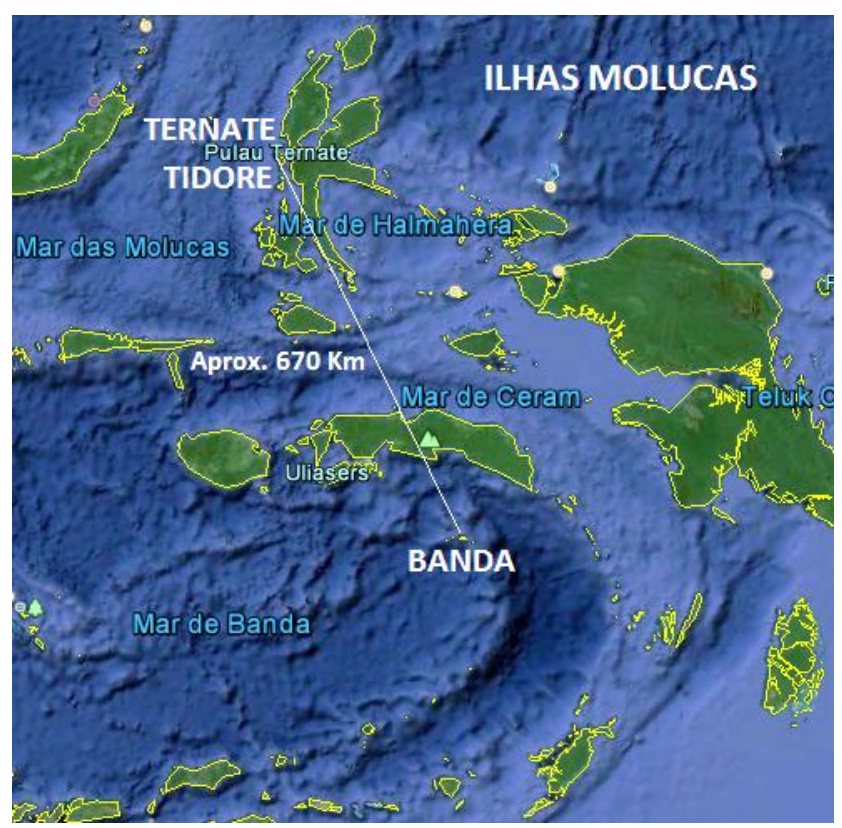

Fonte: Google Earth (2015)

Apesar de longínquas, na era Paleozóica (há aproximadamente 200 milhões de anos atrás), todas as massas continentais existentes estavam concentradas e conectadas em um supercontinente, a Pangeia, assim denominado pelo meteorologista alemão Alfred Wegener, em 1920. Posterior a esta era geológica, a quebra do supercontinente originaria durante o Mesozoico duas grandes porções de terra - a Laurásia no hemisfério Norte, e o Gondwana no hemisfério Sul - continuando o processo de separação até a formação dos continentes que conhecemos na atualidade (Teoria da Deriva Continental). Assim, a diferenciação dessas plantas teria seguido seu curso, dando a elas características próprias.

\section{O QUINTO SABOR}

Do período das Grandes Navegações à atualidade, os temperos fazem parte de uma expressiva quantidade de ingredientes na cozinha. Em busca da comodidade e da praticidade em preparar pratos, os alimentos industrializados ganharam destaque, trazendo consigo os temperos prontos à base de glutamato monossódico (GMS), os quais imperam entre os condimentos mais utilizados no mundo, alcançando, em 2007, a produção de 2 milhões de toneladas (SANO, 2009).

Descoberto em 1908 pelo pesquisador japonês Kikunae Ikeda, da Universidade Imperial de Tókio, o glutamato monossódico tornou-se amplamente conhecido em 
1866, com sua produção industrial e comercialização pela empresa Ajinomoto® (AULT, 2004).

Encontrado na composição de muitos alimentos, como o tomate, milho, ervilha, e na maioria das sopas, molhos, salgadinhos, embutidos e temperos prontos, o GMS é o sal sódico do ácido glutâmico (GLU), um importante aminoácido não-essencial sintetizado em quase todas as células do nosso organismo - e precursor do neurotransmissor GABA (ácido gama-aminobutírico) (CARVALHO et al., 2011). O GLU foi isolado pela primeira vez em 1866 por meio da hidrólise da gliadina - um peptídio encontrado em algas e no glúten do trigo (Figura 11).

Figura 11: Formula estrutural do ácido glutâmico, glutamato monossódico e GABA<smiles>NC(CCC(=O)O)C(=O)O</smiles>

ácido glutâmico<smiles>NC(CCC(=O)O)C(=O)[O-]</smiles>

glutamato monossódico<smiles>NCCCC(=O)O</smiles>

GABA

Fonte: Acervo pessoal

O GMS é utilizado na indústria alimentícia para melhorar a palatabilidade e realçar o sabor de diversos produtos. Em contato com água, presente nos alimentos e na saliva, o glutamato monossódico se dissocia. Em sua forma livre, este aditivo é o responsável por ofertar um sabor diferenciado aos alimentos conhecidos como Umami (o quinto sabor) - expressão japonesa que significa "delicioso".

Atualmente, o glutamato monossódico é produzido através da fermentação de açúcares - principalmente oriundos da cana de açúcar e do milho. Esta tecnologia, desenvolvida no Japão em 1956, foi aprimorada ao longo dos anos e continua sendo empregada nos dias de hoje (SANO, 2009).

Embora pareça estranho considera-lo um sabor devido à dificuldade de caracteriza-lo nos alimentos como fazemos com um salgado ou um doce, ou até mesmo 
ao experimentarmos o azedo do limão e o amargo do jiló, a percepção do Umami é realizada através de receptores de membrana localizados na região central da língua. $\mathrm{O}$ GMS em contato com células receptoras gustativas desencadeia um potencial de ação e a liberação de cálcio, sinalizando às terminações nervosas que interpretam a resposta como um sabor específico (SAN GABRIEL et al., 2009; KINNAMON, 2009; CHAUDHARI; PEREIRA; ROPER, 2009). Postula-se ainda que o efeito realçador de sabor do GMS possa ser resultado de sua interação com receptores gustativos minimizando a percepção do gosto amargo (DUTCOSKY, 2007).

Além do aminoácido glutamato, também podemos sentir o gosto Umami quando experimentamos alimentos ricos em alguns nucleotídeos, especialmente o inosinato e o guanilato (Figura 12). Devido ao acentuado efeito sinérgico do GMS com sais dissódicos, como os dois compostos descritos, encontrados, respectivamente, em carnes, peixes e cogumelos, é indicado utilizar o glutamato com moderação nestes alimentos, pois, ao interagir com estes, produz efeito até seis vezes maior ao esperado (DURÁNMÉRAS et al., 1993).

Figura 12: Fórmula estrutural do inosinato e guanilato

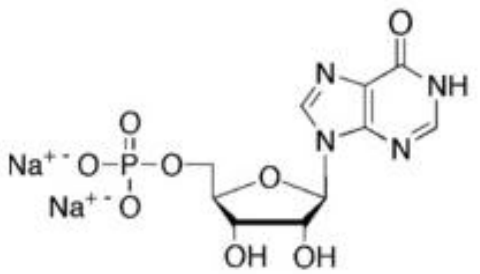

inosinato<smiles>N#[N+]OP(=O)(OCC1OC(n2cnc3c(=O)[nH]c(N)nc32)C(O)C1O)O[N+]#N</smiles>

guanilato

Fonte: Acervo pessoal

Embora críticas massivas sejam feitas ao uso do glutamato em alimentos, suscitando opiniões arbitrárias ao binômio sabor-saúde, diversos comitês o consideram seguro, sustentando deste modo a decisão de governos de todo mundo em aprovar e regulamentar seu uso. Dentre os órgãos que consideram o glutamato inócuo, podemos citar: FDA (Food and Drug Administration) - órgão governamental dos Estados Unidos da América correspondente a Agência Nacional de Vigilância Sanitária, ANVISA, no Brasil -; e SCF (Scientific Committee for Food) - Europa. Ainda que relatórios aleguem que consumir glutamato monossódico não cause danos ao organismo, muitos especialistas dizem o contrário, uma vez que receptores glutâmicos têm sido 
encontrados tanto no sistema de condução elétrica do coração quanto no músculo do coração em si, o que pode estar associado a problemas cardíacos.

A concentração de GMS utilizada em alimentos usualmente varia entre 0,20\% a $1 \%$, contudo, é possível encontrar alimentos no mercado, como cremes e sopas, que trazem uma variação de 1 a $7 \%$ na concentração deste aditivo, superando as concentrações indicadas para uso como realçador de sabor (RODRIGUEZ; GONZÁLEZ; CENTURIÓN, 2003; GUIMARÃES; LANFER-MARQUEZ, 2005). Vale dizer que o glutamato ainda não tem estabelecido um valor máximo para a Ingestão Diária Aceitável (IDA), o que gera receio em muitos consumidores.

Para a comunidade científica que defende seu uso, o GMS quando usado conjuntamente ao sal (proporção 2:1) pode auxiliar na redução do consumo deste, o qual no Brasil é o dobro do sugerido pela Organização Mundial da Saúde (OMS) - (Tabela 3), favorecendo a hipertensão arterial e outras doenças cardiovasculares (SARNO et al., 2009).

Tabela 3: Consumo diário de sal

\begin{tabular}{cc}
\hline & $\begin{array}{c}\text { CONSUMO DE SAL } \\
\text { (em gramas diárias por pessoa) }\end{array}$ \\
\hline Brasil & $\pm 12 \mathrm{~g}$ \\
\hline Indicado pela OMS & $4-6 \mathrm{~g}$ \\
\hline
\end{tabular}

Fonte: Sarno et al. (2009)

\section{CONSIDERAÇÕES FINAIS}

Como é possível perceber, muitos exemplos cotidianos relacionados aos alimentos carecem de interpretação que pode ser explorada e elucidada em aulas de Química. Enquanto professores desta disciplina, temos em mãos ferramentas para explicar, à luz desta Ciência, os fenômenos cotidianos que nos cercam, além da oportunidade de realizar um diálogo efetivo entre as disciplinas e seus conteúdos.

A riqueza conceitual do tema alimentos e seu potencial educativo é um dos caminhos para aproximar o aluno do conhecimento científico, assim como, um viés de interlocução com outras áreas do conhecimento de modo que se note a inter-relação dos conteúdos tratados na escola, ou seja, a possibilidade de um trabalho interdisciplinar. Somado ao exposto, Moura e Santos (2006) afirmam que a interdisciplinaridade tem por intuito superar o tratamento fragmentado do ensino tradicional e contribuir para a 
construção de uma visão mais adequada à complexidade do conhecimento. Isso se dá, pois, muitos conceitos não pertencem exclusivamente a um determinado campo, e por isso, devem ser tratados sob uma perspectiva global.

Nesta ótica, a química torna-se uma abordagem universal e uma linguagem para se explicar fenômenos triviais, mas não óbvios, do nosso dia a dia. Em suma, o ensino através da Ciência é o escopo desta proposta que contempla uma educação para além da sala de aula, com um ensino interessante e relevante/significativo. Em outras palavras, precisamos tornar a aula vivida e sentida, resgatando a função da escola: promover que os alunos tenham prazer em aprender e conhecer.

\section{REFERENCIAS}

ABREU, R. G.; LOPES, A. C. A interdisciplinaridade e o ensino de Química: uma leitura a partir das políticas de currículo. In: SANTOS, W. L. P.; MALDANER, O. A. Ensino de Química em Foco. Ijuí: Ed. Unijuí, 2010.

ALONSO, J. R. Tratado de fitomedicina: bases clínicas e farmacológicas. Buenos Aires, Argentina: ISIS Ediciones SRN, 1998. p.750-753.

AULT, A. The monosodium glutamate story: the commercial production of MSG and other amino acids. Journal of Chemical Education, 81(3), pp. 347-355, 2004.

CARVALHO, P. R. R. M.; BOLOGNESI, V. J.; BARREIRA, S. M. W.; ROCHA GARCIA, C. E. Características e segurança do glutamato monossódico como aditivo alimentar: artigo de revisão. Visão Acadêmica, Curitiba, v.12, n.1, jan./jun., 2011.

CEDRÓN, J. C. La capsaicina. Revista de Química PUCP. Pontificia Universidad Católica del Perú. p. 7-9, vol. 27, n. 1-2, 2013.

CORREIA, P. R. M.; DAZZANI, M; MARCONDES, M. E. R.; TORRES, B. B. A Bioquimica como ferramenta interdisciplinar: vencendo o desafio da integração de conteúdos no Ensino Médio. Química Nova na Escola, n. 19, p. 19-23, maio, 2004.

CHAUDHARI, N.; PEREIRA, E.; ROPER, S.D. Taste receptors for umami: the case for multiple receptors. American Journal of Clinical Nutrition, 90, pp. 738-742, 2009.

CHEMELLO, E. A química na cozinha apresenta: as cebolas. Revista Eletrônica ZOOM da Editora Cia da Escola. São Paulo, Ano 6, n.2, 2005. Disponível em: < http://www.quimica.net/emiliano/artigos/2005jun_qnc_cebola.pdf $>$. Acesso em: 15/09/2016.

DURÁN-MERÁS, I.; PEÑA, A.M.; ESPINOSA-MANSILLA; A., SALINAS, F. Multicomponent determination off flavor enhancers in food preparations by partial least 
squares and principal component regression modeling of spectrophotometric data. Analyst, 118(7), pp. 807-813, 1993.

DUTCOSKY, S.D. Análise sensorial de alimentos. Curitiba: Universitária Champagnat, 2007.

GUIMARÃES, C.P., LANFER-MARQUEZ, U.M. Estimativa do teor de fenilalanina em sopas desidratadas instantâneas: importância do nitrogênio de origem não-protéica. Revista Brasileira de Ciências Farmacêuticas, 41(3), pp. 365-375, 2005.

IMAI, S.; TSUGE, N.; TOMOTAKE, M.; NAGATOME, Y.; SAWADA, H.; NAGATA, T.; KUMAGAI, H. Plant biochemistry: An onion enzyme that makes the eyes water. Nature, 419:685-685, 2002.

KINNAMON, S.C. Umami taste transduction mechanisms. American Journal of Clinical Nutrition, 90, 753-755, 2009.

LE COUTEUR, P; BURRESON, J. Os botões de Napoleão: as 17 moléculas que mudaram a História. Tr. De Maria Luiza X. de A. Borges. Rio de Janeiro: Jorge Zahar Ed., 2006.

MASSABNI, A. C. Capsaicina: da pimenta para usos terapêuticos, 2010. Química Viva, Conselho Regional de Química - IV Região. Disponível em: <http://www.crq4.org.br/quimica_viva_capsaicina>. Acesso em: 22/09/2015.

MOURA, A. M.; SANTOS, W. L. P. Percepção de professores do Ensino Médio sobre interdisciplinaridade em projetos de educação ambiental. In: ENEQ, 13, 2006, Campinas. Anais. Campinas-SP, 2006, 1 p. CD-ROM.

NUNES, F. B.; OLIVEIRA, J. R.; PEREIRA, P. L. M.; CARÁ, V. M. Receptores Sensoriais. In: OLIVEIRA, J. R. (org.) Biofísica: para ciências biomédicas. p. 97-108, 4 ed - Porto Alegre: EDUPUCRS, 2014.

OHSE, B. J. G.; FUSCALDI, J. L.; BUSO, G. S. C.; CARVALHO, S. I. C.; REIFSCHNEIDER, F. J. B.; FERREIRA, M. E. Ausência de ardor em pimenta causada por SNPs detectados no gene Pun1 de Capsicum annuum. $56^{\circ}$ Congresso Brasileiro de Genética, Guarujá-SP, v.1, 2010.

PEIXOTO, F. M. C. Alguns aspectos químicos do odor. Química, 52, p.30-33, 1994.

RANA, S. V.; PAL, R.; VAIPHEI, K.; SHARMA, S. K.; OLA, R. P. Garlic in health and disease. Nutrition research reviews, 60-71, 2011.

RETONDO, C. G.; FARIA, P. Química das sensações. Campinas, SP: Editora Átomo, 3 ed., 2009.

REYES, F. G. R. (org.) Umami e glutamato: aspectos químicos, biológicos e tecnológicos. Editora Plêide, 2013. 
RODRIGUEZ, M.S., GONZÁLEZ, M.E., CENTURIÓN, M.E. Determination of monosodium glutamate in meat products. The Journal of the Argentine Chemical Society, 91(4/6), p. 41-45, 2003.

SANO, C. History of glutamate production. American Journal of Clinical Nutrition, 90: 728-732, 2009.

SAN GABRIEL, A.; MAEKAWA, T.; UNEYAMA, H.; TORII, K. Metabotropic glutamate receptor type 1 in taste tissue. American Journal of Clinical Nutrition, 90, 743-746, 2009.

SARNO, F.; CLARO, R.M.; LEVY, R. B.; BANDONI, D. H.; FERREIRA, S. R.; MONTEIRO, C. A. Estimativa de consumo de sódio pela população brasileira, 20022003. Revista Saúde Pública, 43(2), p. 219-25, 2009.

SILVA, D. D.; NEVES, L. S.; FARIAS, R. F. História da química no Brasil. Campinas, SP: Editora Átomo, $4^{\mathrm{a}}$ Ed., 2011.

STADLER, Z. Determinação do Teor de Vitamina C em Alimentos. Curitiba, 1999. Monografia apresentada ao Curso de Especialização em Ensino de Química Experimental. Setor de Ciências Exatas, Departamento de Química, Universidade Federal do Paraná.

VERRUMA, M. R.; SALGADO, J. M. Análise química do leite de búfala em comparação ao leite de vaca. Sci. Agric., Piracicaba, 51(1): 131-137, jan./abr.,1994. 